\title{
ÚJRATERVEZÉS - A KÓRHÁZSULI ALAPÍTVÁNY GYORS ÉS RUGALMAS VÁLASZAI A COVID-19 JÁRVÁNY IDEJÉN
}

\author{
TÓTHNÉ ALMÁSSY MONIKA
}

\begin{abstract}
DOI: https://doi.org/10.53585/OnkSzem.2021.2.56-69
Absztrakt
\end{abstract}

A KórházSuli Alapítvány az iskolából tartós betegség miatt kimaradó fiatalok oktatásrehabilitációs folyamatának támogatását végzi, önkéntes egyetemisták és középiskolások közremúködésével. A cél megvalósításához az oktatási- és egészségügyi szektor szakembereinek a bevonásával egy olyan keretrendszert dolgoztak ki, ahol mind a segítők, mind a segítettek megfelelő támogatást kapnak a közös tevékenység biztonságos és sikeres elvégzéséhez. A COVID-19 járvány kezdetén a meglévő keretrendszert áthelyezték teljesen az online térbe, és megnyitották a tanulás lehetőségét az egészségügyi dolgozók gyermekei, valamint a krónikus beteg gyerekek számára is. Az esettanulmány célja annak bemutatása, hogy a COVID-19 járvány milyen hatással volt a szervezet múködésére és az önkéntesek tevékenységére. Bemutatjuk, hogy milyen kihívásokkal kellett szembenézni és azokra milyen válaszok születtek. Továbbá, milyen szempontok alapján történt az újabb támogatást igénylő csoport kiválasztása, hogyan zajlott az új önkéntesek toborzása, felkészítése, valamint a megnövekedett számú résztvevő munkájának operatív irányítása. Részletezzük, melyek voltak a program során felmerülő nehézségek a múködés, az önkéntesek, az egészségügyi dolgozók és a technika oldaláról, és ezekre milyen megoldások születtek. Bemutatásra kerül, hogy a KórházSuli Alapítvány életére milyen pozitív hatással volt a járvány alatti extra feladatok felvállalása és sikeres elvégzése. Az esettanulmány elkészítéséhez az adatok a szervezet statisztikai- és hatásvizsgálati anyagaiból származnak. Az extra tevékenység vizsgálata időrendi sorrendben, az önkéntesek fókuszba állításával történt.

Kulcsszavak: oktatásrehabilitáció, COVID-19 járvány, online tanulás, önkéntes toborzás, KórházSuli Alapítvány,

\section{Replanning - rapid and flexible responses of the SchoolHospital Foundation during the COVID-19 pandemic MONIKA TÓTH ALMÁSSY}

\section{Abstract}

The SchoolHospital Foundation supports the education rehabilitation process of children who drop out of school due to chronic illness by the co-operation of high school and university student volunteers. A framework system has been developed with the involvement of experts from both the education and health sector to reach the goal. This system ensures adequate support for both helpers and the ones they help to be able to pursue their common activities in a safe and successful way. The existing

${ }^{1}$ Tóthné Almássy Monika pedagógus, a KórházSuli Alapítvány igazgatója 
framework system was entirely moved to the on-line space at the beginning of the pandemic and the possibility of learning was given for the children of healthcare workers as well as for children living with chronic illness. The aim of the case study is to show the impacts of the COVID-19 pandemic on the operation of the organization and on the activities of volunteers. We will present the challenges the organization had to face and the responses that were given to them. Furthermore, we will show the criteria according to which the new group in need for help was chosen and how the recruitment and preparation of the new volunteers as well as the operational management of the growing number of participants was going on. We will specify the operational and technical problems as well as the difficulties that were encountered by the volunteers and healthcare workers during the program and we will present the answers that were given. We will describe the positive impact of the undertaking and successful completion of extra tasks on the life of SchoolHospital Foundation. The data used for this case study are taken from the statistical and impact assessment documents of the organization. Extra activities were examined in a chronological order, bringing volunteers into focus

Keywords: education rehabilitation, COVID-19 pandemic, volunteering, online learning, SchoolHospital Foundation,

\section{BEVEZETÉS - AZ ALAPÍTVÁNY TEVÉKENYSÉGÉNEK BEMUTATÁSA}

Magyarországon évente körülbelül 1500-2000 gyermek kényszerül arra, hogy baleset vagy súlyos betegség miatt egyéni tanrendben folytassa a tanulmányait, mivel a teljes felépüléshez hónapokig, akár évekig is eltartó kórházi kezelés és otthoni lábadozás szükséges.

A KórházSuli Alapítvány - www.korhazsuli.hu -2014-es megalakulása óta közel 2000 önkéntes bevonásával több mint 700, általános- és középiskolás gyermek felzárkózását, valamint visszailleszkedését támogatta, betöltve ezzel azt a jelenlegi szabályozásból adódó rést, ami az oktatási és egészségügyi ellátórendszerek között kialakult. A programba legtöbbször az otthoni rehabilitáció hónapjai, évei alatt csatlakoznak be a gyógyuló fiatalok, főként kórházi kapcsolattartók és iskolák ajánlásával. A program országos hatókörű, így a segítő-segített párok tartózkodási helyének függvényében személyesen és/vagy az online térben történnek a találkozások. Az önkéntesek alapvetően az otthoni lét alatt segítenek, de az online világ eredményeképp a kórházba való visszakerüléskor - az egészségügyi állapothoz alkalmazkodva - is folytatódhat a közös tanulás.

A KórházSuli program a középiskolások bevonásával indult hét tanévvel ezelőtt, és bázisintézménye a budapesti Eötvös József Gimnázium volt. A második évben bővült a program budapesti egyetemistákkal, akik akkor főként az ELTE hallgatói voltak. A több fővárosi és vidéki egyetemmel, középiskolával kötött együttműködési szerződés eredményeképp az alapítványnál végzett önkéntes munka elszámolható iskolai közösségi szolgálatként, illetve kreditként is. 
A program másik lába, a bázis-kórház, a Magyar Református Egyház Bethesda Gyermekkórháza, de több budapesti és vidéki kórházzal is van együttműködési szerződése az alapítványnak, így például: a 2020/21-es tanévben nyitottuk meg az első vidéki bázist, a Debreceni Egyetem Gyermekgyógyászati Klinikán, ahol az önkéntesek és a KórházSuli pedagógusa együtt dolgoznak a betegágyak mellett.

A KórházSulihoz való önkéntes csatlakozás feltételei:

- a feladatköröknek megfelelő képzésen való részvétel,

- az önkéntes szerződésben vállaltak betartása,

- az esetmegbeszélőn való részvétel,

- e-napló vezetése az önkéntesmunkáról.

$A z$ önkéntesek képzését oktatási és egészségügyi szakemberek - pedagógusok, kórházpedagógus, szociális munkás - tartják. A személyes élmények és kérdések megválaszolásában helyet kapnak a középiskolás és egyetemista mentorok is. A középiskolások attitűd formáló beszélgetésen ismerkednek meg a beteg gyermekek helyzetével, illetve megtanulják a tananyagfejlesztő rendszer használatát. Az egyetemisták számára szervezett 10 órás képzés tartalmazza a beteg gyermekek és családjaik megváltozott életének, az oktatási rehabilitációnak, módszertani és kommunikációs ismereteknek, valamint a segítő kompetenciáinak bemutatását.

A képzés után a középiskolások 2-3 fös csoportokban, az általuk választott tantárgyból, témakörből interaktív, kreatívan feldolgozott tananyagokat fejlesztenek az általános- és középiskolai tananyagokból, a Moodle tananyagfejlesztő rendszerben, önkéntes mentortanárok támogatásával és ellenőrzése alatt. Ugyanakkor, a középiskolások nem állnak személyes kapcsolatban a gyógyuló kortársaikkal. A velük való találkozásra kizárólag szervezett keretek között (tábor, koncert, kiállítás) van lehetőségük. Ez a szabály az ő védelmüket szolgálja.

Az egyetemisták személyes és/vagy online találkozások alkalmával tanulnak együtt a kiválasztott párjukkal felhasználva a középiskolások által fejlesztett tananyagokat. A tanulópárok kiválasztásának szempontjai lehetnek például: a lakóhely közelsége, a betegség típusa, tantárgy, korosztály, valamint érdeklődési kör szerint. A tanulási folyamat az anyaiskola pedagógusaival való folyamatos konzultációval zajlik, megkönnyítve a beteg gyerekek számára a gyógyulás utáni visszatérést. 
A tananyag átadása mellett a tanulópárok abban segítenek, hogy a gyógyuló gyerekek a betegségük ideje alatt is - az állapotukhoz mérten - aktív napokat éljenek, legyenek céljaik és egy támogató közösség tagjai lehessenek. Mindezek nagyban elősegítik a gyógyulásukhoz való pozitív hozzáállást és a könnyebb visszatalálást a betegség előtti életükhöz.

A közhasznú alapítvány a múködéséhez szükséges anyagi fedezetet céges és magán adományokból, pályázatokból, pro bono (CRM rendszer, Moodle tananyagfejlesztő rendszer, jogsegély, fordítások) támogatásokból fedezi. A szervezetben négy főállású alkalmazott dolgozik.

Tanévenként átlagosan 150-170 gyógyuló fiatal kap segítséget, többségük kétszemélyes tanulási folyamatban, azonban több kórházban múködik KórházSuli tanulószoba is. A munkában 250-300 középiskolás és egyetemista önkéntes vesz részt, és 25-30 felnőtt önkéntes támogatja szaktudásával a programot (mentortanárok, szupervizorok, jogász, szervezetfejlesztő, coach). A résztvevők évente összesen 6500-7000 önkéntes órát töltenek el a programban.

A személyes odafigyelés a KórházSuli fő márkaértéke: „Rólad szól, te vagy a középpontban”. Ez egyaránt vonatkozik a segített gyógyuló fiatalokra és a segítő önkéntesekre. A beteg gyerekek egyénre szabott segítséget kapnak a tanulmányaik folytatásához, az önkéntes fiatalok pedig megkapnak minden szakmai (képzések és továbbképzések, támogató csoportok) és mentális (rendszeres, kötelező, csoportos esetmegbeszélők, személyes coaching alkalmak, gyászfeldolgozás) támogatást ahhoz, hogy a lehető legbiztonságosabban éljék meg a kapcsolódást a beteg gyerekekkel, hogy védett környezetben tapasztalhassák meg a segítségnyújtás örömét. Mindeközben egy értékteremtő közösség részeként fejlődik a személyiségük, kreativitásuk, együttmúködési készségük.

„2018 szeptemberében csatlakoztam a KórházSulihoz, igazából csak azért, mert valahogy segíteni szerettem volna, a beteg gyerekek napjait jobbá tenni. Akkor még nem gondoltam, hogy én sokkal többet fogok kapni az alapítványtól, mint amennyit én tudok adni. Már az elsö képzésen éreztem azt a határtalan szeretetet, ami benne volt a levegőben, és amit még mindig minden egyes beszélgetéskor, programkor érzek. Itt mindenkire figyelnek, ugyanannyira ránk, egyetemistákra, mint a középiskolásokra vagy épp a segített gyerekekre. Ez tetszett meg nagyon, és emiatt éreztem, hogy nekem nagyon is itt a helyem." Maácz Fruzsina, egyetemista önkéntes

Az önkéntesek hosszú távú elköteleződését a személyes odafigyelésen túl, az elmúlt hét év alatt kiérlelt és a visszajelzésekhez igazított, szakmai alapokon nyugvó keretrendszer is biztosítja. Ennek főbb elemei az alapítvány munkatársai által kifejlesztett képzési és 
továbbképzési rendszer; a tevékenység folyamatos monitorozása (alapja kötelezően vezetett e-napló; rendszeres email és telefonos megkeresés az egyik fóállású munkatárs által); személyes visszajelzések; szükség esetén beavatkozás, szakmai mentorálás önkéntes pedagógusok által; esetmegbeszélők; előmeneteli rendszer; váltás a különböző tevékenységek között; közösségi megmozdulások; együttműködési szerződések az oktatási intézményekkel (elszámolható órák, kreditek); egyéni pályautak (ajánlások ösztöndíjakhoz, munkavállaláshoz, szakdolgozat, kutatások) támogatása. Nem elhanyagolható szempont az sem, hogy mivel a tanulás párokban folyik, a csatlakozó önkéntesek közvetlenül megtapasztalják a munkájuk eredményét, egy interaktív folyamat szereplői mind a személyes találkozások, mind az online kapcsolódások alkalmával.

\section{A KÓRHÁZSULI PROGRAM HATÁSVIZSGÁLATA}

Az alapítvány fontosnak tartja a folyamatok és az eredmények nyomon követését, és minőségbiztosítási okokból - szükség esetén a beavatkozást. A 2019/20-as tanévben féléves hatásvizsgálati képzés eredményeképp megszületett az a mérési rendszer, amely az idei, 2020/21-es tanév szeptemberében bevezetésre is került. A hatásvizsgálat során mind a csatlakozó önkénteseket, mind a segítséget kérő családokat megkérdezzük. A bemeneti és kimeneti kérdések (például a csatlakozás célja, miben szeretne fejlődni az önkéntes munka során szakmailag és személyiségében) eredményei egy adatvizualizációs program segítségével rögtön láthatóvá is válnak. A tanév végi kiértékelés után, az eredmények tükrében - az elengedhetetlen módosítások érdekében - megtörténnek a szükséges lépések.

Az egyik bemeneti pont az önkéntesek motivációját vizsgálja, hiszen a tevékenység megszervezésénél nagyon fontos, hogy a csatlakozó önkéntesek elégedetten, az elvárásaikat beteljesítve tudják vállalt feladataikat teljesíteni.

Nagyon pozitívnak tartjuk, hogy a fiatalokat nem csak az egyetem felé elszámolható kreditek mozgatják elsősorban az önkéntes munkára, hanem a segítségnyújtás, a társadalmi szerepvállalás, a személyiségükben bekövetkező pozitív változás is (1. ábra). 
1. ábra „Mi a csatlakozásod célja?” kérdésre adott válaszok megoszlása (az összes, 413 válasz százalékában)

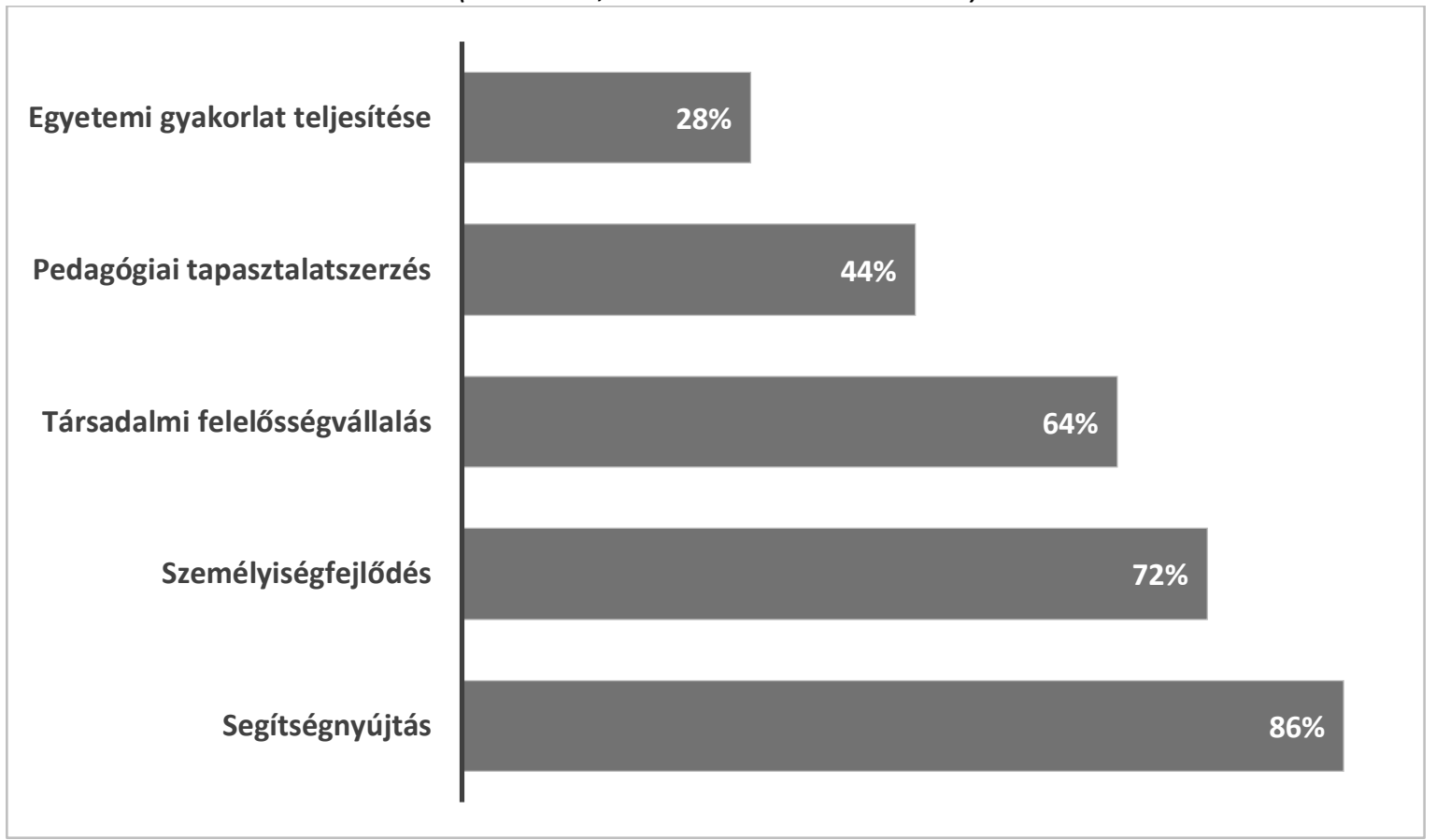

Forrás: KórházSuli adatbázis 2020/21-es tanév, saját szerkesztésü ábra

2. ábra „Kérlek válaszd ki, miben szeretnél fejlődni személyiségedben az önkéntességed során?” kérdésre adott válaszok megoszlása (az összes, 414 válasz százalékában)

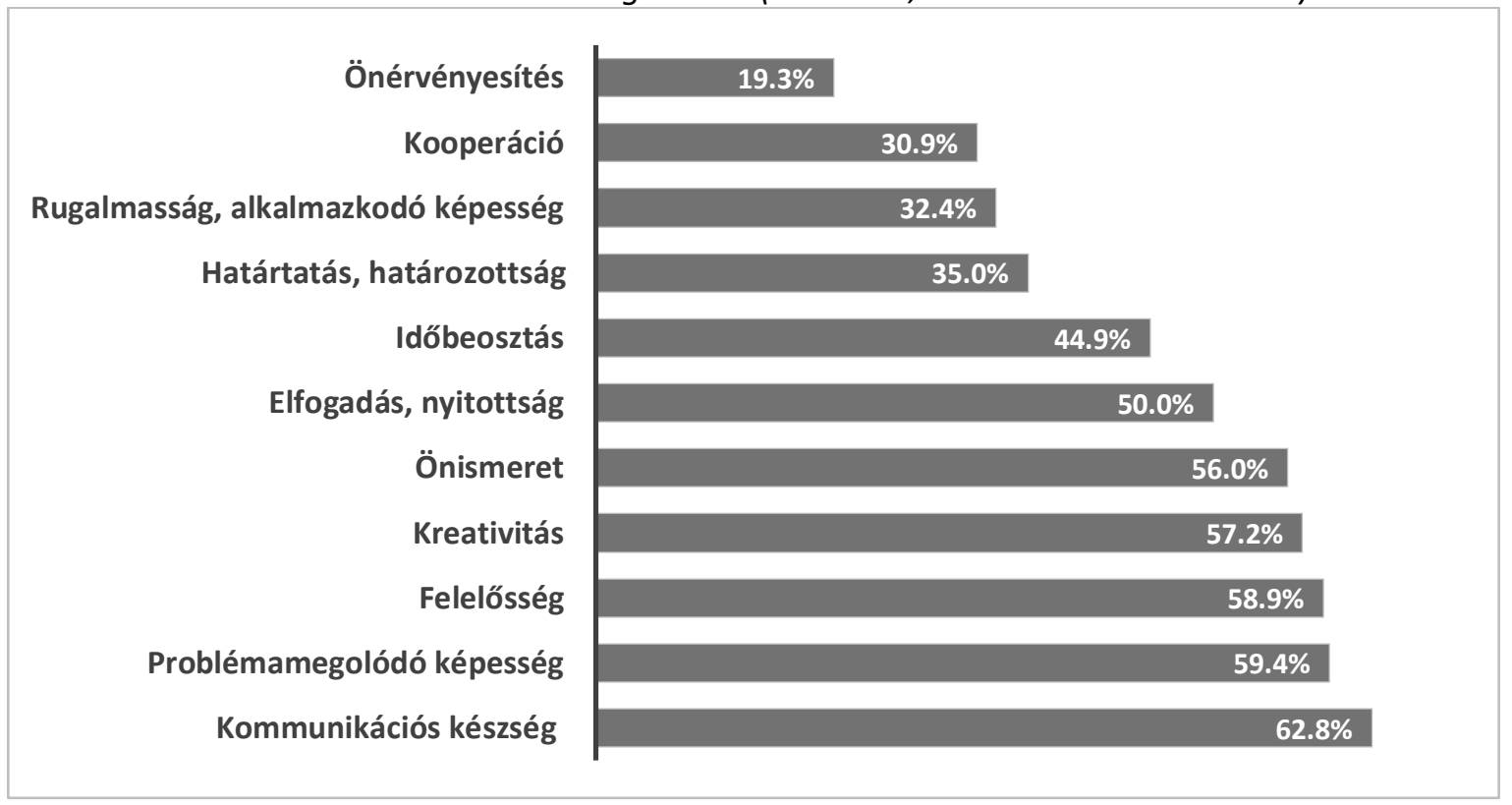

Forrás: KórházSuli adatbázis 2020/21-es tanév, saját szerkesztésü ábra

Ahogy a 2. ábra is mutatja, az egyetemisták a kommunikációs és a problémamegoldó készségükben, kreativitásukban, önismeretükben, valamint a felelősségvállalásban szeretnének fejlődni az önkéntesség által. 
3. ábra „Kérlek, válaszd ki, miben szeretnél fejlödni szakmailag az önkéntességed során?” kérdésre adott válaszok megoszlása (az összes, 414 válasz százalékában)

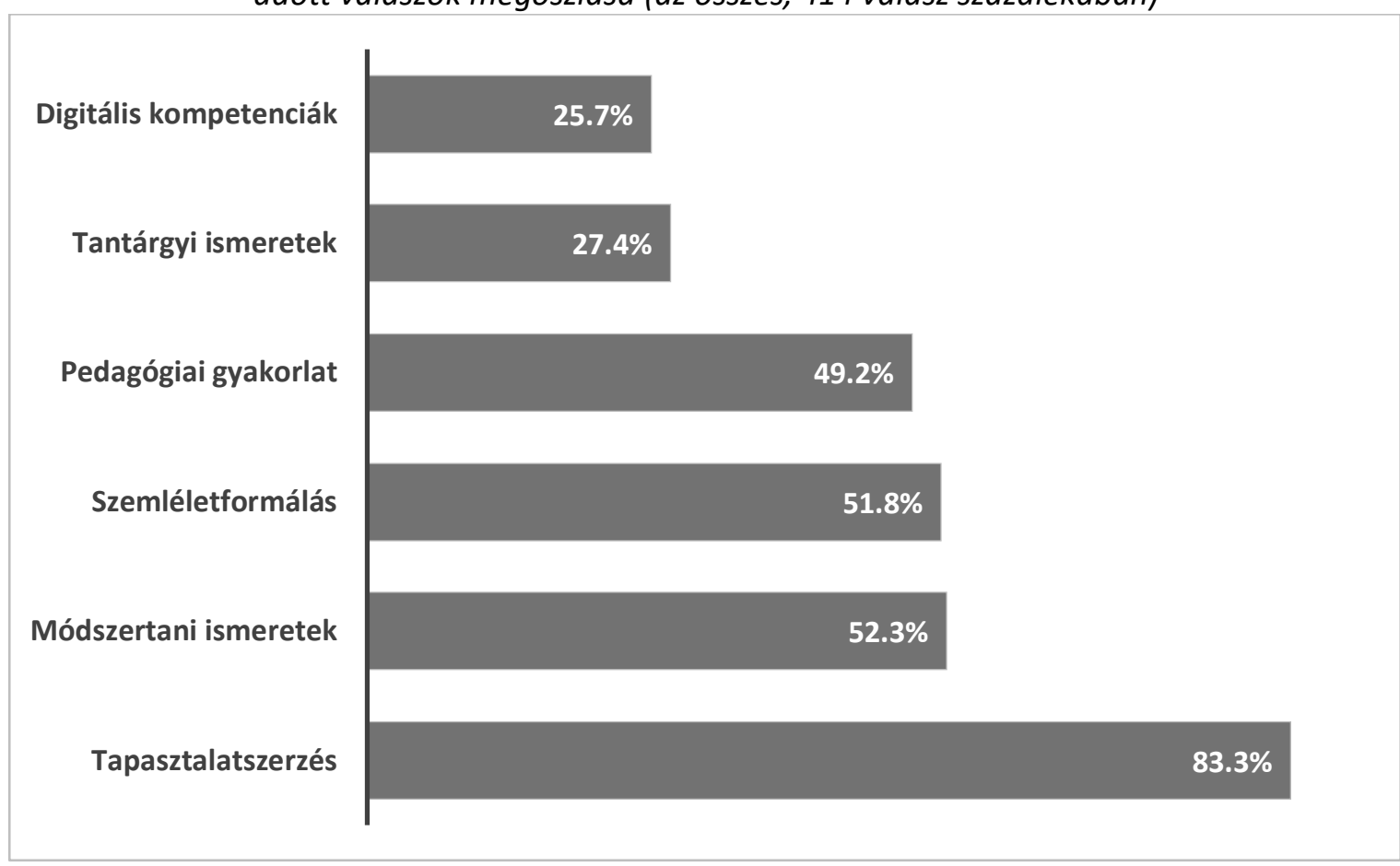

Forrás: KórházSuli adatbázis 2020/21-es tanév, saját szerkesztésü ábra

A felsőoktatásban részt vevő fiatalok számára nagyon hiányzik az elméleti képzés kiegészítéseként a gyakorlatban megszerezhető tapasztalat. Ezért, ahogy a 3. ábrán is látható, sokakat ennek lehetősége motivál az önkéntességre, az alapítványhoz való csatlakozásra.

\section{A COVID-19 HATÁSA A SZERVEZET MÜKÖDÉSÉRE ÉS AZ ÖNKÉNTESEK TEVÉKENYSÉGÉRE - KIHÍVÁSOK ÉS VÁLASZOK}

A 2020 márciusi iskolai bezárások után a KórházSuli Alapítvány az alaptevékenység folytatásával párhuzamosan megszervezte az egészségügyben dolgozók gyermekeinek online oktatását. Felhasználva az addigi tapasztalatokat - a koronavírus okozta rendkívüli oktatási helyzet nehézségeinek mérséklésére - online tanulószobák és tanulópárok szerveződtek az egészségügyi dolgozók gyermekeinek megsegítésére és foglalkoztatására.

A koronavírus okozta helyzet mozgósította a megoldást kereső embereket. A program óriási sikerének egyik kulcsa a bejelentés utáni azonnali reagálás volt. Az alábbi, 1. táblázat az elmúlt és idei tanév számait mutatja a normál működés és a COVID-19 helyzetre kínált programban. 
Az első hullám alatt a normál múködés mellett 216 egészségügyi dolgozó gyermeke 3000 fölötti megtartott tanórában 393 önkéntes támogatásával tanult.

1. táblázat A KórházSuli Alapítvány müködése az 2019/20 és a 2020/21 tanév első felében

\begin{tabular}{|c|c|c|c|c|}
\hline & \multicolumn{2}{|c|}{ 2019/20 tanév } & \multicolumn{2}{|c|}{$\begin{array}{l}\text { 2020/21 tanév } \\
\text { (2021.04.30-ig) }\end{array}$} \\
\hline & $\begin{array}{l}\text { Normál } \\
\text { program }\end{array}$ & $\begin{array}{l}\text { Covid "Online } \\
\text { tanítok" }\end{array}$ & $\begin{array}{l}\text { Normál } \\
\text { program }\end{array}$ & $\begin{array}{l}\text { Covid "Online } \\
\text { tanulok" }\end{array}$ \\
\hline Segített diákok száma & 144 & 219 & 127 & 36 \\
\hline tanulópárban & 57 & 184 & 127 & 36 \\
\hline tanulócsoportban & 87 & 35 & - & - \\
\hline Önkéntesek száma & 304 & 393 & 320 & 46 \\
\hline egyetemista & 169 & 343 & 235 & 25 \\
\hline középiskolás & 120 & 20 & 65 & 21 \\
\hline felnőtt & 15 & 30 & 20 & 5 \\
\hline Megtartott tanórák & $1200+$ & $3000+$ & 1860 & 770 \\
\hline $\begin{array}{l}\text { Feldolgozott tananyagok } \\
\qquad(\mathrm{db})\end{array}$ & 95 & - & 35 & - \\
\hline Önkéntes munkaóra & $2000+$ & 6000 & 6087 & 1540 \\
\hline
\end{tabular}

Forrás: KórházSuli 2019/20 és a 2020/21 tanév, saját szerkesztésü ábra

A második és harmadik hullámban ötödére csökkent a segített diákok száma, aminek oka az, hogy az iskolák már fel tudtak készülni az újabb bezáródásokra, így a diákok nem igényeltek külső segítséget mindennapi tanulmányaikhoz.

Az alapprogramban résztvevő önkéntes egyetemisták száma 66 fóvel emelkedett az idei tanévben. Ez mindenképp az előző tanév kiterjesztett múködésének az egyik sikermutatója. A középiskolás önkéntesek száma azonban azért csökkent felére az idei tanévben, mert egy új tananyagfejlesztő rendszer bevezetésének az előkészületei zajlanak, ezért új jelentkezők toborzása nem történt. 


\section{A program legfontosabb mérföldkövei}

1. Helyzetfelmérés COVID-19 első hullám - 2020. március-június (iskolai tanév vége)

A program vezetője a munkatársakkal való egyeztetés után gyors döntést hozott. A KórházSuli rendszere rugalmas, ezért a kizárólagosan online oktatásra is gyorsan átalakitható. A rendszert megnyitották tágabb célcsoport, azaz a kórházi dolgozók gyermekei számára is.

\section{Célcsoportok kijelölése}

A KórházSuli egyik közvetlen partnerei az egészségügyi intézmények, ahonnan a segítséget kérő beteg gyerekek érkeznek a programba. Közülük sokan megtapasztalták már a közös tanulás eredményességét.

Az önkéntes fiatalok számára is egyik napról a másikra feje tetejére állt a világ, ők sem járhattak iskolába. Az alapítvány munkatársai fontosnak tartották, hogy a megváltozott körülmények ellenére is megmaradhassanak a segítő szerepükben. Ez célokat adott nekik, a másokra való odafigyelés pedig erőt adott számukra a nehéz napok alatt.

\section{Tevékenység: „Online tanítok”}

Megszületett az "Online tanítok” program ötlete. A pandémia legelején a legtöbb iskolában egyáltalán nem volt tanítás. A közösségben tartás érdekében osztályszinteknek megfelelő tanulócsoportok szerveződtek. A jelentkezők órarend szerint naponta 2-3 tanórán tudtak részt venni. Időközben beindultak az iskolai tanórák is, ehhez alkalmazkodva több csoport felbomlott, tagjaik személyes mentorokat kaptak az általuk igényelt tantárgyakból (ez a KórházSuli „normál” működése).

Az első hullám 13 hete alatt 219 gyereknek 363 középiskolás és egyetemista önkéntes 30 önkéntes mentor tanár támogatásával több mint 3000 tanórát tartott.

\section{Mozgósítás: önkéntesek toborzása}

A mozgósítás a KórházSuli Facebook oldalán, egy sajtóközlemény kiadásával, a meglévő oktatási és egészségügyi kapcsolatok bevonásával történt, akik közül sokan további intézményeket vontak be a programba. Az óriási résztvevő szám szinte egy hét alatt toborzódott. A felsőoktatási intézmények 65 Karáról érkeztek az önkéntesek, Erasmusösztöndíjas hallgatók is bekapcsolódtak a munkába, kilenc országból. Az önkéntes jelentkezők 84 százaléka addig még nem vett részt a programban. Főbb motivációik a csatlakozásra a következők voltak: 
- a hirtelen felszabadult idő: az egyetemek, középiskolák, a szabadidős lehetőségek bezártak, így a diákok átmeneti időre megnövekedett szabadidővel rendelkeztek,

- a társadalmi szerepvállalás vágya: sokan keresték a helyüket, a saját eszközeikkel hogyan tudnának támogatni másokat ebben a rendkívüli helyzetben,

- saját mentális egészségük megtartása: a napi rutin, a keretek fenntartása érdekében,

- a másokért vállalt felelősség: ami erőt ad, eltereli a figyelmet a nehézségek alatt; az értelmes célokért összeálló közösségnek megtartó ereje van.

Összesen 87 kórházi osztályról érkeztek a kérések, több új kórház, főként a keleti régióból, csatlakozott a programhoz. Régi vállalati támogatók és újak kapcsolódtak be eszköz, internet és anyagi felajánlásokkal a programba. ${ }^{2}$

\section{Felkészítés és nyomon követés}

Az alapítvány munkatársai az alaptevékenység során egy jól múködő rendszer egyszerűsített változatát igyekeztek biztosítani ebben az akut helyzetre kidolgozott programban is. A csatlakozó önkéntesek nagyobb csoportokban, rövidített, kétórás alapképzést kaptak a program céljáról, az online felület használatáról, az operatív kérdésekről, az igénybe vehető módszertani támogatásról és az eszköz lehetőségekről. Kijelölt időpontokban fogadóórák voltak a személyes problémák megbeszélésére. A KórházSuli alapprogramban is segítő, valamint újonnan jelentkező mentor tanárok álltak a háttérben, a szakmai kérdések megválaszolására. Ahogy az alapítvány „normál” programjában úgy a Covid-időszakban is, a Magyar Szupervizorok és Szupervizor-Coachok Társasága biztosította a csoportos esetmegbeszélő alkalmakat, amelyek bejelentkezés alapján szerveződtek. Az önkéntesek enaplót vezettek a tevékenységükről, amit folyamatosan figyelemmel kísértek az alapítvány munkatársai, és elakadások esetén telefonos segítséget nyújtottak. Az oktatási intézményekkel kötött megállapodás szerint a megtartott órák elszámolásra kerültek az önkéntesek számára az iskolai közösségi szolgálati órák és egyetemi kreditek formájában.

\footnotetext{
${ }^{2}$ A kezdetektől a következő támogatók állnak a KórházSuli mögött: fő támogató a Telenor Magyarország - az anyagi támogatáson túl korlátlan Hipernetet biztosítanak a program résztvevői számára, anyagi támogatás nyújt a Richter Gedeon Nyrt. és a Roche Magyarország Kft. A jogi szolgálatásokat a Budlegal Ügyvédi Társaság, a CRM rendszert a Soulware Zrt., a tanananyagfejlesztő rendszert a Klippe Learning biztosítja.
} 


\section{A program során felmerülő nehézségek}

A múködés oldaláról. Noha a KórházSuli jól kidolgozott keretrendszere biztosította az alapokat, mégis voltak olyan elemek, amelyek bár a biztonságos múködést szolgálják, megvalósíthatatlanok voltak. Ilyen például az „Alapkő letétel”, a segítő-segített pár, szülő, alapítványi munkatárs első találkozása a célok és operatív részletek megbeszélésére. Ennek hiánya többször jelentett fennakadásokat. A hirtelen szerveződés és a kapacitás hiány miatt a képzéseket nem lehetett a kellő mélységben megtartani, aminek a hiányosságait egyedileg kellett orvosolni, és ez sokszoros energiát igényelt. Merültek fel határtartási nehézségek „Mondhatok-e nemet, ha a szülő további órákat szeretne kérni?” „Mit tegyek, ha nem jelentkezik be a gyerek az órára?" Módszertani kérdések is okoztak fennakadást, amelyekkel nem keresték meg a mentortanárokat automatikusan, az önkéntesek.

Mindeközben az alapítványi alaptevékenységnek is folytatódnia kellett és az új feladatok koordinálására nem tudtunk plusz munkaerőt bevonni, ezért a munkatársak elképesztően leterheltté váltak.

Az oktatási rendszert is váratlanul érte a karantén, ezért minden intézmény kereste a saját megoldásait. Mivel ez mind a segítő, mind a segítetti oldalt egyaránt érintette, ezért az ehhez való alkalmazkodáshoz nagy rugalmasságra volt szükség. Például, kezdetben kizárólag csoportos tanulást szerveztünk azért, hogy a gyerekeknek megmaradjon a kortárs közösségük. Az iskolai online órák fokozatos beindulásával voltak csoportok, amiknek tagjai áttértek az egyéni tanulásra, de voltak olyanok is, akik annyira megkedvelték egymást, hogy az iskolai órák mellett is folytatták a munkát.

Az önkéntesek oldaláról. Egy hét leforgása alatt 300-nál több fiatal csatlakozott a programhoz, akiknek 84 százaléka még nem dolgozott a KórházSuli programban. Az együttműködés nehézségét fokozta az online tér, a személyes találkozások és beszélgetések, egymás megismerésének a hiánya. Továbbá, a jelentkező fiatalok különböző intézményekből jöttek, más-más elgondolással, előzetes ismeretek nélkül. Jellemző volt, hogy sokan rögtön a bezáródáskor, az első impulzusra csatlakoztak a felhíváshoz, időközben viszont beindult a tanítás az ő intézményeikben is, ami több fiatal számára óriási összevisszaságban zajlott. Így előfordult olyan, hogy némelyikük az egyik pillanatról a másikra elérhetetlenné vált, ez pedig - tanulócsoportok esetén különösen - az egész csapat munkájában fennakadást jelentett. 
Az egészségügyi dolgozók oldaláról. Amilyen egyszerü volt az önkéntesek toborzása, annál több egyeztetést igényelt az egészségügyi dolgozók bevonása. A legnehezebb rész a velük való kommunikáció volt. A leterheltségük és az online kommunikációban való járatlanságuk miatt lassan válaszoltak az email-ekre, ilyenkor telefonon kellett őket elérni, ami szintén plusz időt igényelt, és mindezek késleltették a csoportok indulását.

Technikai oldalról. Az „Online tanulok” programba a bekapcsolódás Zoom felületen történt, és a kezdeti időben gyakoriak voltak a rendszeren belüli változtatások, amelyek fennakadást okoztak. Erre nagyon sok esetben ugyancsak az alapítvány munkatársainak kellett megoldást találni. Több jelentkezőnél gondot jelentett az eszköz és az internet hiánya, aminek megoldására céges támogatókat vontunk be, akik tabletet, laptopot és internet elérést biztosítottak a résztvevők számára. Ennek a megszervezését és célba juttatását szintén az alapítvány végezte.

\section{$A z$ „Online tanítok” program eredményei}

A három hónapi közös munka mindenki számára értékes volt, hisz a középiskolások és az egyetemisták aktív szereplőivé váltak egy programnak, egy összefogásnak. Ráadásul a gimnazisták közül sokan lehetőséget kaptak arra, hogy a programban való részvétel által teljesítsék a kötelező iskolai közösségi szolgálatukat. A tanév zárásakor kérdőíves megkérdezés által kerültek összegzésre a tapasztalatok, amelyben az egyik kérdés éppen a karantén-tanítás személyiségre ható változására vonatkozott. A válaszadók által legtöbbet említett fejlődési pontok a türelem, a kommunikációs készség, rugalmasság, kreativitás, empátia fejlődése voltak. Íme néhány idézet a gimnazisták 2020. március-júniusi e-naplójából, illetve az egészségügyi dolgozók visszajelzéseiből.

„Legnagyobb siker az egymásra hangolódás, egymásra figyelés volt számomra."

„Kifejezetten felemelö élmény volt a közös együttlét. Minden olyan apróság, ami korábban problémaként jelentkezett (digitális közvetettség, kommunikációs nehézségek, figyelmi problémák) mind-mind eltüntek, és úgy telt el a 40 perc, mintha nem is lett volna. Sok humorral, sok információval, valódi tanulási élménnyel lettünk gazdagabbak. És utána egész nap mosolyogtam"

„Igazán felemelö élmény volt értesülni arról, hogy középiskolásként is taníthatok fiatalabb gyermekeket a Kórházsuli keretein belül. Lelkesen vettem fel a kapcsolatot velük, hiszen nem sok lehetöségem volt addig segíteni a járvány ideje alatt a négy fal közül. Végre úgy éreztem, hogy én is hozzáteszek valamit ahhoz, hogy másoknak könnyebb legyen túlélni ezt a krízishelyzetet. Egy nagyon lelkes, értelmes fiúval találtam szemben magam a kamera túloldalán. Az órák nagy jókedvvel folytak, megismertem azokat az online felületeket, amik könnyebbé teszik a kommunikációt. Igazán remélem, hogy a túloldalon is hasonló élményekröl számolnak be." 
„Rengeteg és hatékony segítséget kapott a kislányom matematikából Tőled. A kezdeti lemaradást hamar pótoltátok. Személyre szabottan, nagyon jól, érthetően elmagyaráztad a gondot jelentö feladattípusokat, sokat gyakoroltatok nagyon kedves, barátságos hangulatban. Lili sokat fejlödött, saját szavaival: „szinte brillírozott időnként matekból."

„Nagyon hálásak vagyunk Neked, remek tanár, rugalmas és nagyon szimpatikus vagy. Lili nagyon megkedvelt. Megnyugtató volt, hogy rendszeresen, pontosan jelentkeztél, már zajlott az óra mindig, mire hazaérkeztem. Köszönjük szépen a segítségedet."

\section{A második és a harmadik hullám (2020 szeptember - 2021 június): az „Online tanulok” program}

A 2020/21-es tanévben is folytatódott az „Online tanítok” program, ami kibővült a krónikus betegek számára felajánlott „Online tanulok” programmal. Ebben olyan tanulók vettek részt, akik normál esetben iskolába jártak, de a krónikus betegségük miatt a veszélyeztetett csoportba kerültek, és így szülői döntésre az otthoni tanulást választhatták.

A második és harmadik hullámban a segítséget kérők száma ötödére csökkent. A legfőbb ok az volt, hogy a 2020/21-es tanév kezdetén az iskolák a normál múködésükkel kezdték meg a tanítást. $\mathrm{A}$ bezáródás elrendelése már jóval felkészültebben érte őket, mint az első hullám alatt, így a legtöbb iskolában online tanítás kezdődött, nem maradtak magukra a gyerekek.

Az önkéntesek is iskolába jártak, illetve az egyetemistáknak folyamatos online óráik voltak, valamint a megnövekedett beadandó feladataik jelentős idejüket lefoglalta. Ennek ellenére voltak olyan tanulópárok, akik az első bezáródás óta nem hagyták abba közös tanulást.

\section{ÖSSZEGZÉS}

A legfontosabb és legmeghatározóbb érték az alapítványi munkatársak helytállása volt a járvány időszakában, hiszen Nélkülük a program nem múködött volna. Ismét bebizonyították az ügy iránti elkötelezettségüket, az egymásra és a másokra irányuló kiemelkedő odafigyelésüket, empátiájukat, magas szintű problémamegoldó képességüket, kreativitásukat.

$A z$ "Online tanítok" programban részt vevő önkéntesek hatására a felsőoktatás több intézményében is híre ment a KórházSulinak, ezáltal az előző tanévekhez képest az idén kiemelkedően nagyszámú, 413 fő önkéntes jelentkezett a programba.

A bezáródás és az online platformok kizárólagos használatára való átállás tapasztalatai azt mutatták, hogy vannak olyan események, amelyek idő- és energiahatékonyság céljából a jövőben is az online térben maradhatnak (például az „Alapkő” beszélgetések, rövidebb 
továbbképzések, megbeszélések). Tanulság az is, hogy vannak olyan operatív feladatok, amik a hirtelen érkező nagy létszámú jelentkező miatt egyszerúsíteni kellett, és az idő bebizonyította, hogy így is jól múködnek, ezért az egyszerűsített változat kerül a jövőben is alkalmazásra.

A programmegvalósítás időszaka kivételes szerencsének köszönhetően, egybeesett egy olyan pályázattal, ami a társadalmi bázisépítés megerősítését támogatta. Így lehetősége volt az alapítványnak egy kommunikációs és egy adományszervező munkatárs megbízására, akik az online és offline médiában terjesztették a COVID-19 alatt megvalósított programunk hírét, továbbá tartották a jelentkező adományozókkal a kapcsolatokat, amelyek ma is élnek.

Végezetül munkánk társadalmi elismerésének tartjuk, hogy a KórházSuli 2021 áprilisában elnyerte azt a SozialMarie európai társadalmi innovációs díjat, amellyel minden évben tizenöt kiemelkedő projektet tüntetnek ki. 